\title{
Relationship between Emotional Intelligence and Commitment to Change among Senior Administrative and Diplomatic Service (ADS) Officers in Malaysia
}

\author{
Mohd Sabri Ramly ${ }^{\mathrm{a}}$, Mahaliza Mansor ${ }^{\mathrm{b}}$ \\ ${ }^{a}$ Faculty of Management and Economics, Universiti Pendidikan Sultan Idris, msabri07@gmail.com \\ ${ }^{b}$ Faculty of Management and Economics, Universiti Pendidikan Sultan Idris, mahaliza@fpe.upsi.edu.my
}

\begin{abstract}
The purpose of this study is to investigate the relationship between emotional intelligence and commitment to change among senior Administrative and Diplomatic Service (ADS) officers attached to the federal government ministries in Putrajaya/Kuala Lumpur. The data were collected in a form of questionnaire where a total of 360 senior officers participated in this research. The measurements used comprised the Wong and Law Emotional Intelligence Scale (WLEIS) by Wong and Law (2002) and Commitment to Change by Herscovitch and Meyer (2002). The result of multiple regression analysis showed that one dimension of emotional intelligence namely self-emotion appraisal has a positive relationship with all dimensions of commitment to change. Whereas, all dimensions of emotional intelligence were found to have a positive relationship with one dimension of commitment to change namely the affective commitment to change. Thus, it was noted in this study that the emotional intelligence was found as an important factor in enhancing the level of commitment to change among senior ADS officers. This finding would serve as an indicator to the high-level management of civil service to take into account the element of emotional intelligence especially in upskilling ADS officers' emotional intelligence competencies.
\end{abstract}

Keywords:

Emotional intelligence, ccommitment to change, organizational change

\section{INTRODUCTION}

Malaysia civil service had gone through many stages of reformation since independence in 1957 but the major phase of public service reforms began in the 1980s with early initiatives such as the Look East Policy, Clean, Efficient and Trustworthy, and privatization programme (Siddique, 2014). Some of the major elements in public service reforms were the changes in the systems and procedures, inculcation of values and changes in attitude, introduction of the new technology as well as new management tools (Saleh, 2008; Siddique, 2010). In the early 90s, more practices and approaches were also introduced to reengineer the public sector such as the Malaysia Incorporated, Total Quality Management, Client Charters, ISO 9000, Public-Private Partnership, Privatisation, Quality Management Standard and online public services (Abdullah \& Kalianan, 2008). Malaysian government reforms continuously implemented through the current Government Transformation Programme (GTP), a plan to transform the way the Malaysian government operates and accelerate changes to achieve what had already been planned towards Vision 2020 (Thaib, 2015). Even though many efforts have been done by the public sector, there are also critics about the less impact (Siddiquee, 2006) and other setbacks which brought dissatisfaction among the public (Siddiquee, 2014). These setbacks brought the question on how far is the commitment by the public sector leaders in implementing the government's reform initiatives. Studies conducted by an independent body showed that the Malaysian public 
sector needs to improve on transparency and accountability as those are the culprits that make a number of reform programs and policies faced implementation setbacks (Nur Barizah, Zakiah \& Muslim, 2011). Statistically, in the aspect of public service delivery during the last five years (2015-2011), there were 500 and 600 complaints received per month with delays in taking action and failure in the enforcement being the most frequent complaints (Mohd Shahar, 2016). In average, the number of complaints for the category of 'delay/no action/not met complainants' need' and 'unsatisfactory quality of service' represent between $40.6 \%$ to $61.3 \%$ of the total complaints received per year from 2012 to 2017 . Even though the number of complaints has dropped every year, but the service delivery of the government still become the main issue. Statistics of complaints received by Public Complaints Bureau from 2013 to August 2017 is shown in Table 1.

Table 1: Measurement items

\begin{tabular}{cccc}
\hline Year & $\begin{array}{c}\text { No. of } \\
\text { Complaints }\end{array}$ & $\begin{array}{c}\text { Delay/No Action/Not } \\
\text { Meet Complainants } \\
\text { Need/ }\end{array}$ & $\begin{array}{c}\text { Unsatisfactory } \\
\text { Quality of Service } \\
(\%)\end{array}$ \\
\hline 2016 & 6,518 & $1,692(26.0 \%)$ & $954(14.6 \%)$ \\
2015 & 6,424 & $2,561(39.9 \%)$ & $623(9.7 \%)$ \\
2014 & 7,218 & $2,728(37.8 \%)$ & $816(11.3 \%)$ \\
2013 & 9,879 & $4,274(43.3 \%)$ & $1,750(17.7 \%)$ \\
2012 & 12,582 & $5,877(46.7 \%)$ & $1,842(14.6 \%)$ \\
\hline
\end{tabular}

Source: Public Complaints Bureau (2017)

The complaints and dissatisfaction among Malaysian citizen reflect the government performance. According to Asnawi, Yunus and Abd Razak (2014), there is a positive relationship between emotional intelligence and commitment to change which contributes to job performance. Commitment to change is also found to has a positive effect on the success of change implementation (Parish, Cadwallader, \& Busch, 2008; Herold, Fedor \& Caldwell, 2007; Wulandri, Mangundjaya, \& Utoyo, 2015). Commitment to change also has a positive impact to the organizational effectiveness such as improved performance (Parish et al., 2008). However, in order to respond and manage changes, one should have emotional intelligence abilities (Goleman \& Chernis, 1998). A study by Fatima, Imran, Ahmed Khan, and Ahmed Khan (2015) showed that emotional intelligence was significantly and positively related to change commitment. This study was not intended to focus on the outcome of the implementation of organizational change but rather focusing on the employee support to organizational change. As suggested by Van der Voet, Kuipers, and Groeneveld (2015), employee support can be seen as an antecedent of successful change implementation.

Thus, the focus of this study is to examine the commitment to change among senior ADS officers who are in the job grade of M54, M52, and M48, attached to 25 federal government ministries in Putrajaya/Kuala Lumpur. Usually, those particular senior ADS officers included in middle management, lead a unit or division in the government's organization structure. This group was chosen because, according to Carter et al. (2014), most of studies focused on top leadership, thus middle leaders have been overlooked by researchers even though the role of lower level managers is recognized to be especially important during the implementation of change. In conclusion, the researcher intends to fill the gap by examining the relationship of emotional intelligence with organizational commitment to change among senior ADS officers in Malaysia. 


\section{LITERATURE REVIEW}

\section{Emotional intelligence}

The beginning of emotional intelligence as a concept started by researchers like Thorndike, Guilford, Binet and Gardner (Salleh, 2009). Thorndike created social intelligence and defined it as the ability to perceive one's own and others' internal states motives and behaviours, and act towards them optimally on the basis of that information (Salovey \& Meyer, 1990). Gardner included Thorndike's social intelligence as part of his theory of multiple intelligence. The term emotional intelligence was first used as early as 1960s by Van Ghent (1961) and Leuner (1966) before it was used extensively in a dissertation by Payne (1986) (Bradberry \& Su, 2006). However, according to Mayer, Salovey and Caruso (2004), only in 1990, two articles explicitly defined and developed the theory of emotional intelligence as well as the demonstration measure of it.

Salovey and Meyer (1990) defined emotional intelligence as the subset of social intelligence that involves the ability to monitor one's own and others' feelings and emotions, to discriminate among them and to use this information to guide one's thinking and actions. The ability model of emotional intelligence proposed by Mayer and Salovey, (1997) and Mayer, Salovey, Caruso and Sitarenios (2001) has a four-branch structure namely Perceive Emotion, Use Emotion to Facilitate Thought, Understand Emotions and Manage Emotion, where each branch corresponds to a basic ability. According to Mayer and Salovey (2004), perceive emotion refers to the ability to recognize emotion in others through facial, voice, and postural expressions. Use emotion to facilitate thought refers to the ability to use emotions to facilitate thinking. Understand emotions refers to the ability to analyze emotion, be aware of their probable trends and understand their result. Manage emotion refers to the ability manage emotion in the context of the individual's goal, self-knowledge, and social awareness which necessarily involves the rest of personality. Wong and Law (2002) introduced a revised fourbranch emotional intelligence ability model namely self-emotion appraisal (SEA), others' emotion appraisal (OEA), use of emotion (UOE), and regulation of emotion (ROE) for measuring individuals' self-perceptions about emotional intelligence. SEA refers to the capacity to understand one's own deep emotions and express it naturally by sensing and acknowledging their emotions well. OEA refers to the capacity to recognize and understand other peoples' emotion while ROE refers to the capacity to manage one's own emotions. The higher level of ROE enables people to alleviate their psychological distress rapidly. UOE refers to the capacity to employ their emotions by leading them towards useful activities and personal performance.

In the context of organizational change, emotional intelligence plays a significant role in making sure the success of the change. Change perceived as challenges to an organization (Asnawi et al., 2014, Van der Voet, Kuipers, \& Groeneveld, 2013) and something that cannot be avoided (Asnawi et al., 2014). Malik and Masood (2015) suggested that emotional intelligence leads to stronger psychological resources which play a significant role in employees' proactive attitudes towards change. Tonder (2004) suggested that emotional intelligence is extremely important to facilitate the acceptance of organizational change.

\section{Commitment to change}

Since organizational commitment is found to be related to organizational outcomes such as job performance, citizenship, absenteeism, and turnover, it has received a great deal 
of research attention (Herold et al., 2008). Meyer and Allen (1997) defined commitment as a psychological state or way of thinking that influences employees to retain attachment in an organization and also proposed a three-component model comprising affective, continuance, and normative commitment. The three components conceptualization components of organizational commitment are (a) Affective commitment- refers to the sense of affection and feelings of attachment to the organization; (b) Continuance commitment - refers to the consciousness of the costs related to parting with the organization or job; and (c) Normative commitment - refers to a sense of requirement to continue employment.

Even though there is growing literature on organizational change, the research on employee reaction to change is still lacking. Thus, the commitment to change model which is the extension to the original concept of organizational commitment was introduced in order to fill the gap and expand the concept of organizational commitment to other forms of workplace commitment (Herscovitch \& Meyer, 2002). This theory is about behavioural support towards change initiatives in the context of organizational change. Herscovitch and Meyer (2002) defined commitment to change as "a force (mind-set) or psychological state that binds an individual to a course of action deemed necessary for the successful implementation of a change initiative" and introduced three-component model of commitment to change comprises of affective commitment to change (ACC), continuance commitment to change (CCC) and normative commitment to change (NCC) which is considered as having similar advantage to those demonstrated in the literature of organizational. ACC refers to a desire to support a change based on a belief in its inherent benefits, $\mathrm{CCC}$ is based on a recognition that there are costs associated with resisting change, and NCC reflects a sense of obligation to be supportive towards change.

In the context of organizational change, a research by the Gartner group revealed that the main reason why change initiatives fail, is due to the inability of the people to adjust their behavior, skills and commitment to their new requirements (Soumyaja, Kamlanabhan \& Bhattacharyya, 2015). Gelaidan and Ahmad (2013) suggested that one of the many reasons why change efforts failed have been argued to lie in humans and their inadequate or lack of commitment to change. Mangundjaya (2013) argued that in order to survive and compete, every organization has to change, and the success of this change lies in the employee, specifically in their commitment to change. Employee commitment to change is extremely important for an organization that is embarking on a change program (Jing, Xie, \& Ning, 2014). Asnawi et al. (2014) asserted that much past research has supported commitment to change as one of the most important factors to support change initiatives. Fatima, Imran, Ahmed Khan, and Ahmed Khan (2015) suggested that managers should attempt to obtain the change commitment of the employees as it has been considered an important factor during the change process.

\section{Relationship between emotional intelligence and commitment to change}

Huy (1999) indicated that an action taken by a person in the direction of change is influenced by emotional receptivity and also depends on necessary commitment to cooperate during the change process. Erikkson (2004) pointed out that there is a positive relationship between emotional intelligence and commitment to change which contributes to job performance. Wong and Law (2002) also indicated that there is a positive and statistically significant relationship between emotional intelligence and commitment to change. A study by Fatima et al. (2015) also shows that emotional intelligence was significantly and positively related to change commitment where individuals with high in emotional intelligence have greater effect on the success of intentional change. 
The past studies which showed significance relationship between emotional intelligence and commitment to change as discussed in this chapter have brought to the proposed hypothesis as follows:

H1: Emotional intelligence consists of self-emotion appraisal, others emotion appraisal, use of emotion and regulation of emotion are positively related to ADS officers' commitment to change which consists of affective commitment to change, continuance commitment to change and normative commitment to change.

\section{RESEARCH METHODOLOGY}

In terms of sampling, since the study was focusing on middle level leaders only, the sample frame covered only the ADS officers from the 48, 52, and 54 grades. The samples were drawn from 25 federal ministries in Putrajaya/Kuala Lumpur. The measuring instrument for data collection was in the form of questionnaires using a 10-point Likert scale ranging from 1 (strongly disagree) to 10 (strongly agree). The reason for choosing a longer scale is because of its several advantages such as, it encourages respondents to spread their ratings across more scale points (Myers, 1999), where it provides respondents with greater choices and discrimination to find the point that is most reflective of their rating (Wittink \& Bayer, 1994). Greater spreads of ratings usually better for advanced statistical analyses, such as correlations, multiple regressions, and factor analysis (Myers, 1999; Wittink \& Bayer, 1994). This theory is also supported by Darbyshire and McDonald (2004) which concluded that longer scales offer the maximum flexibility in the majority of cases.

A total of 1,800 questionnaires were distributed to the selected officers. However, only 394 senior officers participated in this research via the Google Forms online survey application. Out of 394 feedbacks received, only 360 were usable in this study. The response rate of this research was $21.8 \%$ which is considered as low and it probably due to the use of web-based survey. According to Nulty (2008), in general, online surveys do not achieve response rates that are even close to what is achieved with paper-based surveys. Nevertheless, according to Graham (2015), survey response rates has shown dramatic decline over the past three decade. The declining response rate raises significant concerns about the possibility of bias in survey result (Hellevik, 2015; Graham, 2015). The classical paradigm of probability sampling requires a $100 \%$ response rate to guarantee unbiased estimates, but with the declining phenomena of survey response rate, there have been a shift in the way researchers think about nonresponse bias (Graham, 2015). Survey response rate regarded as a key data quality indicator but not necessarily predictive of nonresponse bias (Meterko et al., 2015). A study by Hellevik (2015) indicated that even in the extreme case of nonresponse, most result are not bias and low response rate may have scientific value. Graham (2015) asserted that response rate alone is a fairly poor predictor of nonresponse bias and base on prior research, even as low as $10 \%$ response rate may produce highly accurate estimates in certain cases. Fowler (2002) indicated that there's no agreed-upon standard for a minimum acceptable response rate. Even though the response rate in this study is low, the total feed backs were sufficient since they exceeded the minimum number suggested by Krejcie and Morgan (1970) which is at least 351 for the total population of ADS officers in this study. Based on the arguments above, the response rate of this study can be accepted.

The sampling technique used in this study was stratified random sampling where the respondents were divided into three strata group based on their job grades which are M54, 
M52 and M48. In terms of measuring scale, the Wong and Law Emotional Intelligence Scale (WLEIS) by Wong and Law (2002) was used to measure emotional intelligence in this study. WLEIS scale has 16 items with four items for each of the four factors namely SEA, OEA, UOE and ROE. Wong and Law (2002) considered this instrument as reliable and valid and better alternative for other scales of emotional intelligence. Commitment to change by Herscovitch and Meyer (2002) was used to measure commitment to change among the senior officers who participated in this research. The scale has 18 items with six items for each of the three factors namely ACC, CCC, and NCC. Examples of questionnaire items measuring both constructs are shown in Table 2 .

Table 2: Measurement items

\begin{tabular}{l}
\multicolumn{1}{c}{ Constructs } \\
\multicolumn{1}{c}{ Emotional Intelligence } \\
\hline Self-emotion appraisal (SEA) \\
I have a good sense of why I have certain feelings most of the time. \\
I have good understanding of my own emotions. \\
Others' emotion appraisal (OEA) \\
I always know my friends' emotions from their behavior. \\
I am a good observer of others' emotions. \\
Use of emotion (UOE) \\
I always set goals for myself and then try my best to achieve them. \\
I always tell myself I am a competent person. \\
Regulation of emotion (ROE) \\
I am able to control my temper and handle difficulties rationally. \\
I am quite capable of controlling my own emotions. \\
Affective commitment to change (ACC) \\
I believe in the value of this change. \\
This change is a good strategy for this organization. \\
Continuance commitment to change (CCC) \\
I have no choice but to go along with this change. \\
I feel pressure to go along with this change. \\
Normative commitment to change (NCC) \\
I feel a sense of duty to work toward this change. \\
I do not think it would be right of me to oppose this change.
\end{tabular}

\section{RESEARCH FINDINGS}

\section{Descriptive analysis}

The characteristics of the samples such as gender, age, marital status, highest education level, working experiences, and years in the present job were also collected in this study. The frequencies and percentages used to describe the profile of the senior ADS officers are presented in Table 3. 
Table 3: Distribution of respondents' profile

\begin{tabular}{lrcc}
\hline Variable & $\begin{array}{c}\text { No. of } \\
\text { respondents }\end{array}$ & $\begin{array}{c}\text { Percentage } \\
(\mathbf{\%})\end{array}$ \\
\hline Gender & & & \\
& Male & 167 & 46.4 \\
& Female & 193 & 53.6 \\
\hline
\end{tabular}

Age

$\begin{array}{rcc}30 \text { years and below } & 1 & 0.3 \\ 31-35 \text { years } & 100 & 27.8 \\ 36-40 \text { years } & 150 & 41.7 \\ 41-45 \text { years } & 80 & 22.2 \\ 46 \text { years and above } & 29 & 8.0\end{array}$

Marital Status

\begin{tabular}{rcc} 
Single & 36 & 10.0 \\
Married & 318 & 88.3 \\
Others & 6 & 1.7 \\
\hline
\end{tabular}

Highest Education

\begin{tabular}{rcc} 
Bachelor Degree & 160 & 44.4 \\
Master Degree & 187 & 51.9 \\
PhD & 13 & 3.7 \\
\hline
\end{tabular}

Length of working experience

$\begin{array}{rcc}15 \text { years and below } & 254 & 70.6 \\ \text { 16-20 years } & 64 & 17.8 \\ 21-30 \text { years } & 29 & 8.1 \\ 31 \text { years and above } & 13 & 3.5\end{array}$

Current grade

\begin{tabular}{lcc}
$M 48$ & 187 & 51.9 \\
$M 52$ & 110 & 30.6 \\
$M 54$ & 63 & 17.5 \\
\hline
\end{tabular}

Length of service in current position

$\begin{array}{rcc}\text { Less than 1 year } & 74 & 20.6 \\ \text { 1-2 years } & 115 & 31.9 \\ \text { 3-4 years } & 70 & 19.4 \\ \text { 5-6 years } & 49 & 13.6 \\ \text { 7 years and above } & 52 & 14.5\end{array}$

A majority of the respondents were young with the age between $36-40$ years $(41.7 \%)$. The majority of them had studied at least at Master degree level (51.9\%). More than half were female $(53.6 \%)$ and a majority were young officers who have below 15 years of working experience $(70.6 \%)$. 
Analysis of mean and standard deviation was done for every dimension in each construct and the results are shown in Table 4. Descriptive statistics of data in the table show that the mean and standard deviation values for emotional intelligence varies from 8.02 to 8.59 and 0.96 to 1.08 respectively. Whereas, the mean and standard deviation values for commitment to change varies from 7.59 to 8.24 and 0.85 to 0.99 respectively.

Table 4: Descriptive statistics for measures

\begin{tabular}{lcccc}
\hline Item & Mean & $\begin{array}{c}\text { Std. } \\
\text { Deviation }\end{array}$ & Min & Max \\
\hline Emotional intelligence & & & & \\
\hline Self-emotion appraisal & 8.59 & 0.96 & 5.50 & 10.00 \\
(SEA) & 8.02 & 0.97 & 6.00 & 10.00 \\
$\begin{array}{l}\text { Other-emotion appraisal } \\
\text { (OEA) }\end{array}$ & 8.58 & 0.97 & 6.00 & 10.00 \\
Use of emotion (UOE) & 8.26 & 1.08 & 3.75 & 10.00 \\
$\begin{array}{l}\text { Regulation of emotion } \\
\text { (ROE) }\end{array}$ & & & \\
Commitment to change & & & & \\
\hline $\begin{array}{l}\text { Affective commitment to } \\
\text { change }\end{array}$ & 8.24 & 0.99 & 5.83 & 10.00 \\
$\begin{array}{l}\text { Continuance commitment to } \\
\text { change }\end{array}$ & 7.99 & 0.88 & 5.83 & 10.00 \\
$\begin{array}{l}\text { Normative commitment to } \\
\text { change }\end{array}$ & & 0.85 & 6.00 & 10.00 \\
\hline
\end{tabular}

The reliability of the questionnaire was analyzed based on Cronbach's alpha coefficients. Table 5 shows the Cronbach's alpha values for emotional intelligence and commitment to change variables. It was observed that the Cronbach's alpha values for all the factors exceeded $0.6(>0.6)$ which indicated that the items were reliable for their corresponding factors. Such a high figure indicated that the items were good indicators of what was being measured.

Table 5: Reliability result for the actual study

\begin{tabular}{ccc}
\hline Latent Variables & Number of items & $\begin{array}{c}\text { Cronbach's } \\
\text { alpha }\end{array}$ \\
\hline $\begin{array}{c}\text { Emotional } \\
\text { Intelligence } \\
\text { Commitment to } \\
\text { Change }\end{array}$ & 16 & 0.944 \\
\hline
\end{tabular}

Table 6 shows the result of the Pearson correlation analysis where p-value $=0.000$ was less than $\alpha=0.05$. From the result, there was enough evidence to conclude that there is a correlation between the emotional intelligence and commitment to change among senior ADS officers. Therefore, the coefficient of correlation $r=0.612$ for commitment to change indicates a moderate positive relationship between the emotional intelligence and commitment to change among senior ADS officers. 
Table 6: Measure of correlation

\begin{tabular}{lcc}
\hline & \multicolumn{2}{c}{ Emotional Intelligence } \\
\cline { 2 - 3 } & Pearson & Significance \\
& Correlation (r) & (P-Value) \\
Commitment To Change & 0.612 & $0.000^{* *}$ \\
\hline Notes. Sig. $(0.00<0.05)$. & &
\end{tabular}

\section{Regression results}

To test the hypothesized relationship, multiple regression analysis were adopted. The results of the analysis are shown in Table 7. The results show that one dimension of emotional intelligence namely self-emotion appraisal was found to have a significant impact on all dimensions of commitment to change namely affective commitment to change (ACC), continuance commitment to change (CCC), and normative commitment to change (NCC) which explained about $37.9 \%, 18.3 \%$ and $28.3 \%$ of the variability in ACC, CCC and NCC, respectively. The results also show that all dimensions of emotional intelligence namely selfemotion appraisal (SEA), others emotion appraisal (OEA), use of emotion (UOE) and regulation of emotion (ROE) were found to have a significant impact on one dimension of commitment to change namely ACC which explained 37.9\% variability in ACC.

\section{Table 7: Regression result between emotional intelligence and commitment to change}

\begin{tabular}{lccc}
\hline Independent Variable & \multicolumn{3}{c}{ Commitment to Change } \\
& ACC & CCC & NCC \\
\hline Model Variable & $.18^{*}$ & $.32^{*}$ & $.26^{*}$ \\
SEA & $.11^{*}$ & .07 & .14 \\
OEA & $.28^{*}$ & .01 & .11 \\
UOE & $.16^{*}$ & .08 & .11 \\
ROE & & & \\
& .379 & .183 & .283 \\
$\mathrm{R}^{2}$ & .372 & .174 & .275 \\
Adj R ${ }^{2}$ & $54.15^{*}$ & $19.92^{*}$ & $35.04^{*}$ \\
F Value & & &
\end{tabular}

\section{DISCUSSION}

The findings from the study indicate that emotional intelligence has a significant effect on commitment to change. The result shows that emotional intelligence is a good predictor to the commitment to change among senior ADS officers in the country. This result is in line with past studies conducted by Erikkson (2004), Wong and Law (2002), and Gelaidan and Ahmad (2013). According to Tonder (2004), emotional intelligence is extremely important to facilitate the acceptance of organizational change. The findings also show that affective commitment to change obviously has the strongest significant impact on all components of commitment to change compared to CCC and NCC. This finding is in line with past studies by Herscovitch and Meyer (2002), Meyer et al. (2007), Neves (2009) and 
Parish et al. (2008), which indicate that ACC has the strongest and most consistent positive relation with behavioural support for specific change initiatives. Voet, Steijn \& Kuipers (2016) also claimed that researchers often focus on ACC as it is argued to be the most important antecedent of change-related behaviour. Adil (2016) claimed that employees who are committed to the change at their will or ACC show a greater propensity to comply with the change and therefore, suggested that managers should invest their time in strategizing how they could optimize the level of ACC of their employees. Morin et al. (2015) argued that ACC reflects recognition of the importance and value of the change, and has been linked to the willingness to do what it takes to make the change work.

Generally, ACC is seen as an important condition for the success of change implementation (Herscovitch \& Meyer, 2002). The success of all GTPs or other government change initiatives depends on commitment to change of the employees, especially on the aspect of ACC because based on Mayer et al. (2004), it would eventually lead to job performance of the employees. All management of ministries and department should be aware that these senior level of ADS officers need to have strong emotional intelligence to cope with the dynamic of a fast changing world.

\section{CONCLUSION}

This study is intended to contribute to a growing line of research on the implementation of organizational change in the public sector by providing a theoretical empirical research regarding emotional intelligence and employee commitment to change in the ADS settings. The researcher believes that it would contribute to the body of knowledge as pointed out by Asnawi et al. (2014) that there is an insufficient quantity of literature which examined the relationship between emotional intelligence and commitment to change. This study showed that emotional intelligence cannot be taken for granted in order to assure the success of organizational change. Emotional intelligence is a competency, ability, and skill that needed by most of the individuals to commit to their work (Asnawi et al., 2014). Emotional intelligence competency is an ability to recognize, understand, and use emotional information about oneself that leads to or causes effective or superior performance (Boyatzis, 2008). The present research view emotional intelligence as a competency that is expected to augment positive attitudes toward work, and drive positive behaviour and better outcomes (Sony \& Mekoth, 2016).

Furthermore, ADS officers serve as a consultant to the Malaysian civil service and considered as the 'strategic point of control' in the civil service (Chin, 2011). Undoubtedly, as the progress of transformation agenda is at its peak, it would bring additional working pressure to the ADS officers in every ministry. A study by Mohd Yunus and Mahajar (2011) suggested that ADS officers perceive heavy workload as the main factor which contributes to their stressful condition. The problem of stress could be alleviated through emotional intelligence competencies as suggested by Vratskikh, Masa'dah, Al-Lozi and Maqabeh (2016) that there has been an effect of emotional intelligence in predicting stress levels. Kalyoncu, Guney, Arslan, Guney, \& Ayranci (2012) asserted that several studies have suggested that individuals with high Emotional Intelligence are more capable of understanding and managing their emotions, which allow them to adjust to their surroundings and become more tolerant to challenging conditions including stress. Thus, the management should consider emotional intelligence as an important element especially in capacity building programmes. According to Alsamman, Aldulaimi and Alsharedah (2017), affective commitment to organizational change (ACC) could be enhanced by way of training. 
Attempts should be made to study the actual behavioural reactions to change as well as other attitudes and emotions associated with change. In terms of the instrument used, such as traits-based or combined ability/traits-based emotional intelligence test that could also be used to get a more objective assessment of emotional intelligence than the format used in this study. A more comprehensive study is needed to get a better understanding of the relationship between emotional intelligence and commitment to change. Besides, in this study also, the data collection was conducted using the cross-sectional design. That means, this study was conducted within a short period of time and may not represent the actual picture. Future research work may look into a longitudinal study which involves pre- and post-changes in order to expand the findings.

\section{REFERENCES}

Abdullah, H. S. \& Kalianan, M. (2008). From customer satisfaction to citizen satisfaction: Rethinking local government service delivery in Malaysia. Asian Social Science, 4(11) 87-92.

Adil, M.S. (2016). Impact of change on commitment to technological change, focal and discretionary behaviour. Journal of Change Management, 29 (2) 222-241.

Alsamman, A.M., Abdulaimi, S.H., Alsharedah, M. (2016). Training effectiveness and commitment to organizational change: Saudi Arabian ARAMCO. Management and Administrative Science Review, 5(3), 128-142.

Asnawi, N.H., Yunus, N. \& Abd Razak, N. (2014). Assessing emotional intelligence factors and commitment towards organizational change. International Journal of Social Science and Humanity 4(1) 5-10.

Boyatzis, R.E. (2008). Competencies in the $21^{\text {st }}$ century. Journal of Management Development, 27(1) 5-12.

Bradberry, T. R., \& Su, L. D. (2006). Ability-versus skill-based assessment of emotional intelligence. Psicothema 2006, 18, 59-66.

Carter, M. Z., Self, D. R., Bandow, D. F., Wheatley, R. L., Thompson, W. F., \& Wright, D. N. (2014). Unit-focused and individual-focused transformational leadership: The role of middle leaders in the midst of incremental organizational change, Journal of Management Policy \& Practice, 15(5) 44-53.

Chin, J. (2011), History and context of public administration in Malaysia, public administration in South East Asia: Thailand, Philipine, Malaysia, Hong Kong and Macao. Boca Raton: CRC Press, Taylor \& Francis Group, LLC.

Darbyshire, P. \& McDonald, H. (2004). Choosing response scale label and length: Guidance for researchers and clients. Australasian Journal of Market Research, 12(2) 17-26.

Erikkson, C. (2004). The Effect of change programs on employees' emotions. Personal Review, 33 (1) $110-126$.

Fatima, A., Imran, R., Ahmed Khan, A., Ahmed Khan, H. (2015). Awakening individual's change commitment: The role of emotional and spiritual intelligence in health sector in Pakistan. Journal of Applied Environment and Biological Science, 5(1), 14-19.

Fowler, F.J. (2002). Survey research method ( $3^{\text {rd }}$ Ed.). Thousand Oaks, CA : Sage Publications. 
Gelaidan, H. M., \& Ahmad, H. (2013). The factors effecting employee commitment to change in public sector : Evidence from Yemen. International Business Research, 6(3) 75-87.

Goleman, D. \& Cherniss, C. (1998, October 7). Bringing emotional intelligence to workplace. The Consortium For Research On Emotional Intelligence In Organizations. Retrieved from http://www.eiconsortium.org/pdf/technical_report.pdf

Graham, W. (2015). An empirical examination of the relationship between nonresponse rate and nonresponse bias. Statistical Journal of the IAOS, 31(2015) 305-315.

Herold, D. M., Fedor, D. B., \& Caldwell, S. (2007). The effects of transformational and change leadership on employees' commitment to a change: A multilevel study. Journal of Applied Psychology, 93 (2) 346-357.

Herscovitch, L. \& Meyer, J.P. (2002). Commitment to organizational change: Extension of a threecomponent model. The Journal of Applied Psychology, 87(3) 474-487.

Hellevik, O. (2016). Extreme nonresponse and response bias. Quality and Quantity, 50(5) 1969-1991.

Jing, R., Xie, J. L. \& Ning, J. (2014). Commitment to organizational change in a Chinese context. Journal of Managerial Psychology, 29(8) 1098-1114.

Kalyoncu, Z., Guney,S., Arslan, M., Guney, S., Ayranci, E. (2012). Analysis of the relationship between emotional intelligence and stress caused by the organization: A Study of Nurses. Business Intelligence Journal, 5 (2).

Malik, S.Z. \& Masood, S. (2015). Emotional intelligence and resistance to change: Mediating role of psychological capital in telekom sector in Pakistan. Pakistan Journal of Commerce and Social Sciences, 9(2) 485-502.

Mangundjaya, W. L. H. (August, 2013). The role of leader in organizational change. Proceedings $1^{\text {st }}$ International Seminar of Leadership and Social Change Laboratory of Psychology, Surakarta, Indonesia.

Mayer, J.D., Salovey P., \& Caruso D.R. (2004). Emotional intelligence: Theory, findings and implications. Psychological Inquiry, 15(3), 197-215.

Mayer, J. D., Salovey, P., Caruso, D. R., \& Sitarenios, G. (2001). Emotional intelligence as a standard intelligence. Emotion 2001, 1(3), 232-242.

Mayer, J.D. \& Salovey, P. (1997). What is emotional intelligence. New York: Basic Books.

Meyer, J. P., \& Allen, N. J. (1997). Commitment in the workplace: Theory, research, and application. Thousand Oaks, CA; Sage Publications.

Meyer, J. \& Allen, N.A (1991). Three component conceptualization of organizational commitment. Human Resource Management Review, 1, 61-98.

Mohd Shahar, F. (2016, January 4). Civil Service's Lack of Action Top Grouse. New Straits Times Online. Retrieved from http://www.nst.com.my/news/2016/01/120408/civil-services-lackaction-top-grouse

Mohd Yunus, J. \& Mahajar, A.J. (2011). Stress and psychological well-being of government officers in Malaysia, The Journal of Human Resource and Adult Learning, 7(2) 40-50.

Morin, A. J., Meyer, J. P., Bélanger, É., Boudrias, J. S., Gagné, M., \& Parker, P. D. (2015). Longitudinal associations between employees' beliefs about the quality of the change 
management process, affective commitment to change and psychological empowerment. Human Relations, 69(3), 839-867.

Myers, J.H. (1999). Measuring customer satisfaction: Hot buttons \& other measurement issues, Chicago, USA: AMA.

Neves, P. (2009). Readiness for change: Contributions for employee's level of individual change and turnover intentions. Journal of Change Management, 9(2): 215-231.

Nur Barizah, Zakiah \& Muslim Har (2011). Enhancing Malaysian public sector transparency and accountability: Lessons and issues. European Journal of Economics, Finance and Administrative Sciences, 31 (2011).

Nulty, D. D. (2008). The adequacy of response rates to online and paper survey: What can be done? Assessment and Evaluation in Higher Education, 33(3), 301-314.

Parish, J.T., Cadwaller, S., Busch, P. (2008). Want to, need to, ought to: Employee commitment to organizational change. Journal of Organizational Change Management, 21 (1).

Public Complaints Bureau. (2017). Statistics of complaints by year. Retrieved November $1^{\text {st }}, 2017$, from the Public Complaints Bureau Web site: http://www.pcb.gov.my/en/complaint/statistics-by-year.

Saleh, Z. (2008). Factors that influence the development of governmental accounting in Malaysia. Journal of Accounting Perspectives, 1(December 2008), 57-71.

Salleh, N. M. (2009). The Role of Emotions and Emotional Intelligence During Merger of Two Banking Institutions in Brunei, Unpublished doctoral thesis. University of Southampton, United Kingdom.

Salovey, S. \& Mayer, J. (1990). Emotional Intelligence. Imagination, Cognition and Personality, 9(3), $185-211$.

Siddiquee, N.A. (2006). Public management reform in Malaysia: Recent initiatives and experiences. International Journal of Public Sector Management, 19(4) 339-358.

Siddiquee, N.A. (2014). Malaysia's government transformation programme: A preliminary assessment. Intellectual Discourse, 22(1) 7-31.

Siddiquee, N.A. (2010). Managing for results: Lessons from public management reform in Malaysia. International Journal of Public Sector Management, 23(1) 38-53.

Sony, M. \& Mekoth, N. (2016). The relationship between emotional intelligence, frontline employee adaptability, job satisfaction and job performance. Journal of Retailing and Customer Services, 30 (2016) 20-32.

Soumyaja, D., Kamlanabhan, T.J., Bhattacharyya, S. (2015). Antecedents of employee readiness for change: mediating effect of commitment to change. Management Studies \& Economic Systems, 2 (1) 11-25.

Thaib, L. (2015). PM Najib's transformation agenda in transforming Malaysia into a high income nation. Advances in Research, 3(4), 213-234.

Tonder, V. (2004). Organizational Change: Theory and Practice. Pretoria: Van Schaik.

Van der Voet, J., Steijn, B., \& Kuipers, B.S. (2016). What's in it for others?: The relationship between prososial motivation and commitment to change among youth care professionals. Public Management Review 2016, 443-462. 
Van der Voet, J., Kuipers, B. S., \& Groeneveld, S. (2015). Implementing change in public organizations: The relationship between leadership and affective commitment to change in a public sector context. Public Management Review, 18(6) 842-865.

Van der Voet, J., Kuipers, B.S., Groeneveld, S. (June, 2013) Implementing Change in Public Organizations: The Relationship Between Leadership and Affective Commitment to Change in a Public Sector Context. Presented at $11^{\text {th }}$ Public Management Research Conference, Madison Wisconsin.

Vratskikh, T., Masa'deh, R., Al-Lozi, M. \& Maqableh, M. (2016). The impact of emotional intelligence on job performance via the mediating role of job satisfaction. International Business of Management, 11(2) 69-91.

Wittink, D.R. \& Bayer, L.R. (1994). The measurement imperative. Marketing Research: A Magazine of Management and Applications, 6(4) 14-22.

Wong, C., \& Law, K. S. (2002). The effects of leader and follower emotional intelligence on performance and attitude : An exploratory study. The Leadership Quarterly, 13(3), 243-274.

Wulandri, P., Mangundjaya, W. L. H. \& Utoyo, D.B. (2015). Is Job Satisfaction a Moderator or Mediator on the Relationship between Change Leadership and Commitment to Change. Procedia - Social and Behavioral Sciences, 172(2015), $104-111$. 